Portland State University

PDXScholar

6-1-1968

\title{
Three basic stoneware glazes for cone six oxidation which may be changed in color or texture by the addition of common materials such as sand, clay soil, crushed gravel, or metal filings
}

Carol Hilda Balsiger

Portland State University

Follow this and additional works at: https://pdxscholar.library.pdx.edu/open_access_etds Let us know how access to this document benefits you.

\section{Recommended Citation}

Balsiger, Carol Hilda, "Three basic stoneware glazes for cone six oxidation which may be changed in color or texture by the addition of common materials such as sand, clay soil, crushed gravel, or metal filings" (1968). Dissertations and Theses. Paper 559.

https://doi.org/10.15760/etd.559

This Thesis is brought to you for free and open access. It has been accepted for inclusion in Dissertations and Theses by an authorized administrator of PDXScholar. Please contact us if we can make this document more accessible: pdxscholar@pdx.edu. 
AN ABSTRACT OF THE THESIS OF

$\frac{\text { Carol Hilda Balsiger for the Naster of Science in Teaching in Ceramics }}{\text { (Name) }}$

Date thesis is presented Nay 1, 1968.

Title THRES BASIC STONEWARE GLAZES FOR CONE SIX OX.TDATION WHICH MAY

BE CHANGED IN COLOR OR TEXTURE BY THE ADDITION OF COBMON MATERIAIS

SUCH AS SAND, CLAY SOIL, CRIJSHED Z GPAVEL, OR METAL FILINGS.

Abstract approved

(Major/potessor)

This thesis maintains that glazes may be colored or textured by the addition of common substances such as metal filings, gravels, sands, or local clays.

Three basic glazes were chosen: one transparent, one mat, and one semi-mat. To these basio glazes more than fifty inorganic materials were added in separate test batches. A diversity of results was produced, ranging from a glossy, sand-speokled glaze to a rough glaze made with aluminum shavings; from a white, iridescent glaze made with gypsum to a duIl, gun-metal black glaze made with brass shavings; from a transparent colorless glaze made with aspirin tablets to a dark green trans lucent glaze made with copper filings. This study can be used as the basis for a unit on glazes in a secondary school classroom; its purpose is to serve as an introduction to glazes, while terohing the students an appreciation of some of the earth's abundant raw materials and how they can be used in ceramic glazes. 
THREE BASIC STONEWARE GLAZES FOR CONE SIX OXIDATION WHICH MAY BE CHANGED IN COIOR OR TEXTURE BY TEIS ADDITION OF COMNON MATERIAIS SUCH AS SAND, CLAY SOIL, CRUSHED GRAVEL, OR NETAL FILTNGS.

by

CAROI HILDA BAISIGER

\author{
A THES IS \\ submitted to \\ PORTLAND STATE COLIEGE
}

in partial fulfillment of

the requirements for the

degree of

MASTER OF SCIENCE IN TEACHING

June 1968 
APPROVED:
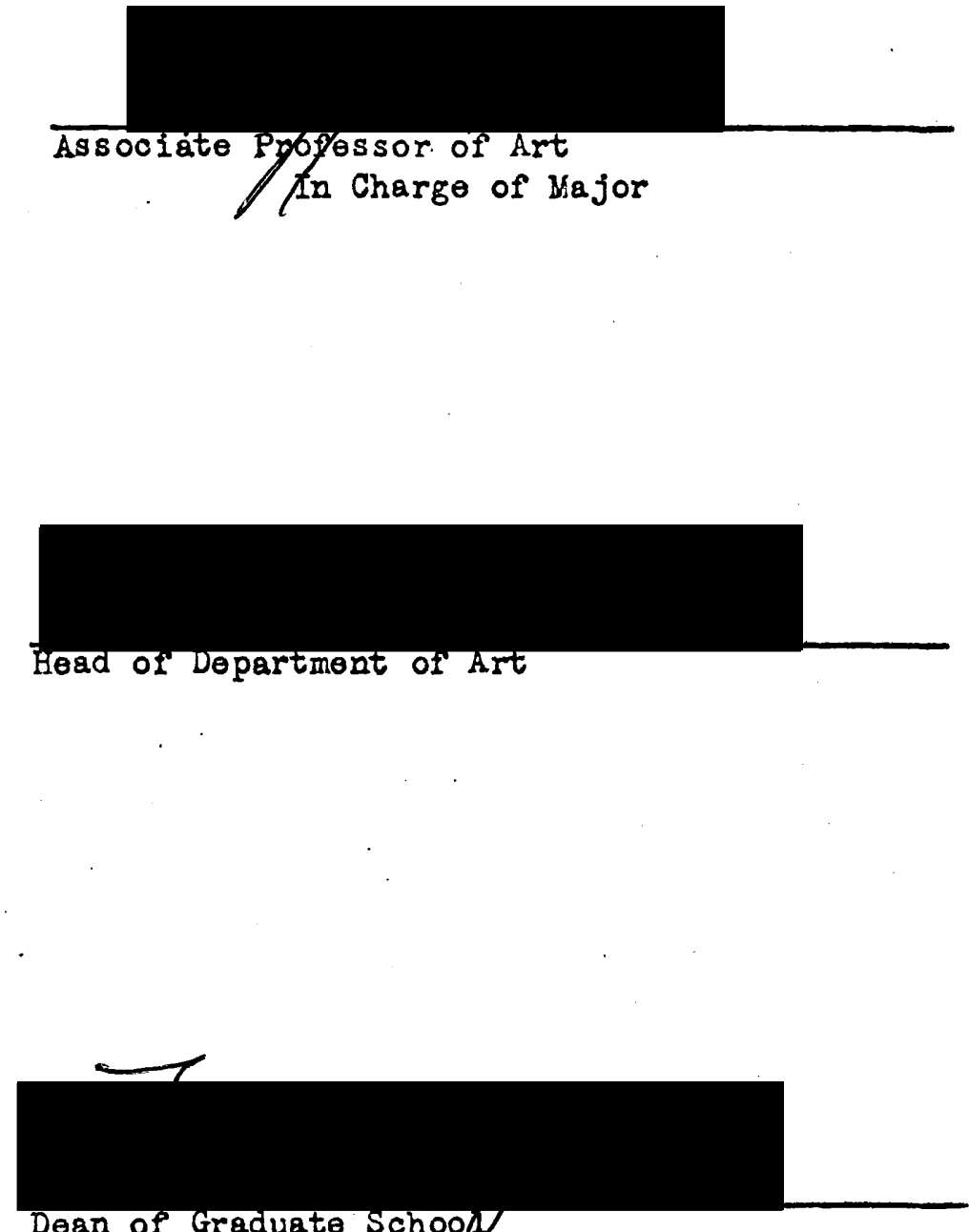

Dean of Graduate schood

Date thesis is presented May 1, 1968

Typed by Carol Balsiger 


\section{TABLE OF CONTENTS}

T. Pago

I. INTRODUCTION . . . . . . . . . . . . I

II. AREA OF STUDY ............... 4

III. THE ADDITION OF COMON MATERIALS . . . . . . 6

IV. ESTHETIC APPLICATION OF GLAZE TO CERAMIC POTS • . I5

V. APPLICATION TO SECONDARY SCHOOL TEACHING . . . 19

VI. SUMMARY AND CONCLUSIONS . . . . . . . . 21

BIBLIOGRAPHY . . . . . . . . . . . 22

APPENDIX .................. 23 
THREE BASIC STONEWARE GLAZES FOR CONE SIX OXIDATION WHICH NAY BE CHANGED IN COIOR OR TEXTURE BY THE ADDITION OF COMMON NATERIALS SUCH AS SAND,

CLAY SOIL, CRUSHED GRAVEL, OR METAL FILINGS.

\section{INTRODUCTION}

The problem considered in this thesis is to investigate what significant changes in the color or texture of a glaze can be gained by adding to it various common inorganic substances.

The purpose of the study is to emphasize the importance of seemingly insignificant sources of materials which can alter the color or texture of a glaze, and to provide the bas is for developing a glaze study project sultable for use in a secondary school art class. There is little information concerning the addition of comon ingredients to glazes.

In our affluent society many persons seldom consider making an artiole if it can be purchased at a store. We have become so sophisticated that we tend to overlook the usefulness of common materials. Our young people need to gain an awareness of what can be done with simple substances. A study such as this will help to overcome this prejudice, because the study focuses on the use of humble materials such as beach sand or soils in glazes. Some of the materials used for the glazes are waste products. For example, the slag tailings from a steel mill, disposed of in unsightly heaps along the riverbank, can be used. This slag creates a rich lustrous browa glaze vinich belies its beginnings. Common substances such as this, often overlooked, can be used to enrich and fulfil our IIves 
through the creation of esthetic forms.

The whole field of ceramics, including pottery, brick and tile, structural clay products, firebrick, porcolain, and sanitary wares, comprises a large portion of our country's industries. These products are all made from the simple, inexpensive raw materials, silica and alumina, the two most common ingredients on the surface of the earth. These two oxides together comprise about three-fourths of the earth's crust. (Green, 1963).

"Clay may be defined as an earthy mineral substance, composed largely of a hydrous silicate of alumina, which becomes plastic when wet, and hard and rock-like when flred." (Rhodes, 1957). The chemical formula for clay is $\mathrm{Al}_{2} \mathrm{O}_{3} \cdot 2 \mathrm{SiO}_{2} \cdot 2 \mathrm{H}_{2} \mathrm{O}$. Clay found in nature, however, is seldom pure. It is combined with other minerals, such as iron, magnesium, calcium, and sodium, all in oxide form.

Glazes are formed from various materials, the chief one being silica: (flint). The other important ingredient, alumina, is a refractory wich resists the effects of high temperatures, has a high melting point, and helps to keep the glaze from running off the pot. It is used in small amounts in the glaze formula.

Most of the other ingredients of glezes serve as fluxes, because they melt at relatively low temperatures and help to lower the melting temperature of the silica.

In addition to the silica and alumina, there are only about fourteen oxides used in hundreds of combinations to produce thousands of basic glazes. These glazes are all essentially colorless, but many colors can be produced by the addition of small amounts of 
coloring oxides. I

"A glaze may bo defined as a glassy coating melted in place on a ceramic body, which may render the body smooth, non-porous, and of a desired color or texture." (Rhodes, 1957).

This Glaze, which can enhance the pot, may get its "desired color or texture" from very humble sources, and it is these humble sources that wo wish to recognize--the significant contribution of insignificant materials.

I See Table 1, Appendix, p. 23. 
II. AREA OF STUDY

I'wenty-oight different glaze rocipos for Cone six ${ }^{2}$ were tested to choose the throe most suitable for the project. These three wore chosen because they wore dissimilar, thus offering a variety of glaze types. One is a dry mat glaze, which is reforred to as Glazo "A"; one is a transparent cracklo glazo, which is referrod to as Glaze "B"; and one is a somi-mat glaze, which is labelod Glaze "C". Another qualification was to use as fow ingredients as possiblo so that secondary school pupils could mix the glazes from a small supply of stock. Eleven ingredients are required. It is loss expensive to buy the supplies and mix the glazes than to purchase prepared glazes.

The recipes follow:

(N Mat Dry Opaque, Cone 5-6)

(F. Carlton Ball)

\begin{tabular}{lr} 
& Porcent \\
Foldspar (Kingman) & 44.3 \\
Ball clay & 1.5 \\
Thiting & 5.6 \\
Barium carbonato & 6.6 \\
Zinc oxido & 19.5 \\
Flint & 16.0 \\
Rutilo & 6.5 \\
\hline & 100.0
\end{tabular}

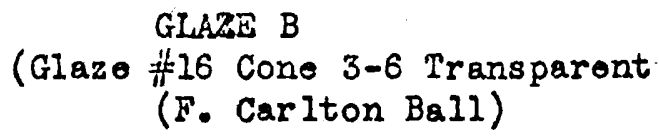

Feldspar (Kingman)

Porcent

Flint

Ball clay

Colemanite

Whiting

Zinc oxide

Barium carbonate

44
24
1
20
2
3
6
100

2 Cone six is $1255^{\circ} \mathrm{C}$ and $2291^{\circ} \mathrm{F}$. 


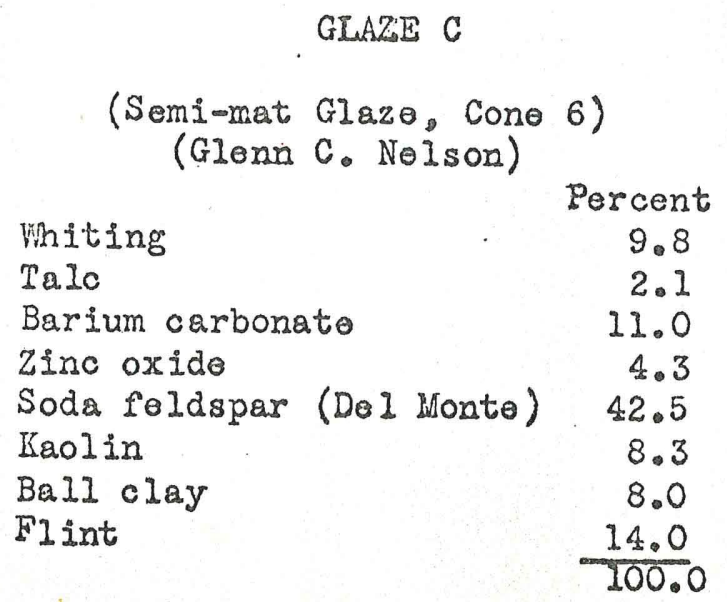

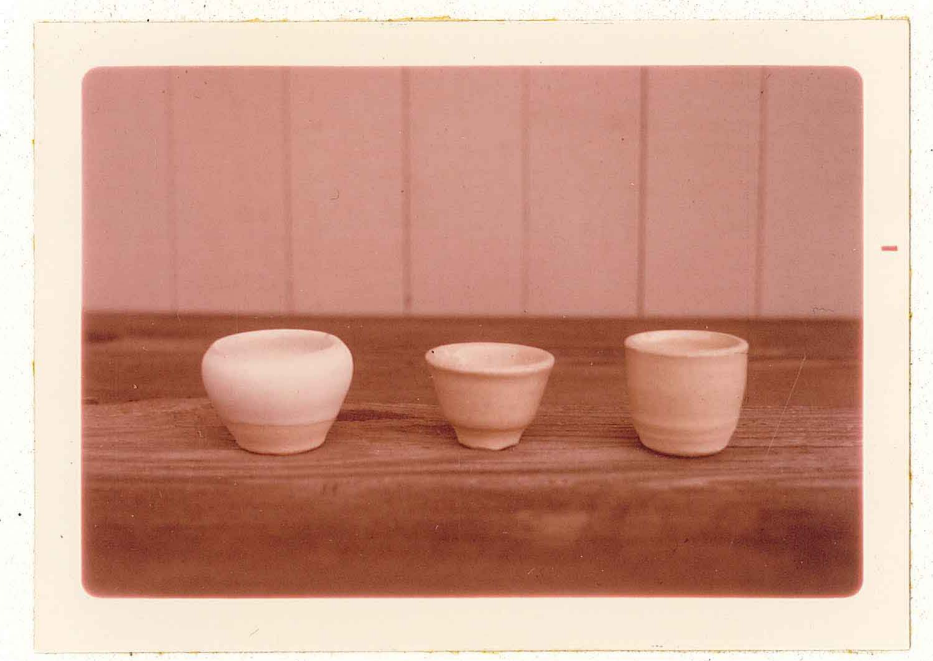

Photograph No. I

Test pota showing basic glazes $A, B$, and $C$.

To theso throo basic glazes common substances were to be added to see how they would affect the color or texture of the basic glaze. Refined chemicals were not used, since these were avajlablo in the ceramics laboratory and presented no challonge. 


\section{THE ADDITION OF COMMON MATERIALS}

Various kinds of materials were used: beach sand, river sand, four different kinds of sand from a foundry, several types of gravol and rocks from gravel companies, local clays from road cuts and slido areas, slag tailings from a steel mill, metal filings from a metals company, kitty-litter, vermiculite, and gypsum wall board. The gravel, rocks, and kitty-littor were made useablo by smashing thom with a hammer on a piece of steel until they were about as fine as table salt. The vermiculite, gypsum wallboard, and clay solls were made finer with a mortar and pestlo. Wany of the items were sifted through a flyscreen. Several of the waste products from Albina Engine and Machine Works had to be washed to remove sand and dirt particlos. Some of the metal sharings and the steol wool pad woro out into approximately one-fourth-inch pieces with scissors. The smaller the size the more likely the additive would become imbodded in the glaze; coarse additives made coarse-textured glazes.

To determine whother the motal filings were likely to melt or to remain intact and become imbedded in tho glaze, the melting point of the motal had to be known. ${ }^{3}$ Not all of the waste metals could bo identified; sóme wore a mixture of more than one metal and other substances.

The items had to be inorganic, since organic materials would burn out during the firing.

3 See Table 2, Appondix, p. 23. 
The test samplos for this study were mado on bisque-fired clay tiles about one-and-one-half-1nches square and one-eighth-inch thick. Nost of the samples were weighed out in ten-gram batches, with ten porcent (one gram) of additive. Ten percent was used because smaller amounts might not make a significant change in the glazo, and larger amounts could change the glaze so greatly that it was no longer a glassy coating on the ware.

One teaspoonful of the mixture was moistened with water to make a creamy paste which was then brushed onto a labeled sample tilo with a one-fourth-inch paintbrush. Sometimes the additive settled to the bottom of the paste so that the mixture had to be stirred each time before painting it onto the test tile. This sottling happonod with the sand, the gravels, the crushed rocks, the motal filings, and the vermioulite. The steel wool clung to itself aftor cutting and was difficult to work with.

When larger amounts of the glazes were used to docorate some test pots, the settling became more of a problem. In one instanco during the glazing application process, the glaze solution was poured into the bowl and quickly emptiod, but a surplus of sand romained deposited inside the bowl.

The coarser sands and gravels settled to the bottom of the liquid glaze mixture. Aftor the glaze was pourod over the pot, more sand was added by dipping into the bottom of the glaze batch with a fingortip and retouching the glazed pot. The vermiculite was thick and poured unevenly. These problems could probably be corrected by using smaller 
amounts of additive in order to reproduce the texture and control tho results.

The following tables list the materials used, the source of the materials, a brief description of each of the throo glazos, and an Indication of its possibilitios as a usoful glazo.. 
TABLE 1.- TEST RESULTS USING SAND

\begin{tabular}{|c|c|c|c|c|}
\hline Description of material & Source & Glaze A & $\begin{array}{l}\text { Rosults in } \\
\text { Glazo } \mathrm{B}\end{array}$ & Useablo $0^{4}$ \\
\hline $\begin{array}{l}\text { White fine-grain sand } \\
\text { zirconite }\end{array}$ & Foundry & Smooth, white & Fine white bubbles & $A B C$ \\
\hline Fine black send. & Foundry & Lt. blue, black & Clear with black particles & $A B C$ \\
\hline Fine white sand & Foundry & Finite & Clear bubbles $\quad$ Clear & $A B C$ \\
\hline Gray sand & Foundry & Blue particles & $\begin{array}{l}\text { Clear with gray particles } \\
\text { salt and poppor }\end{array}$ & $A B C$ \\
\hline Black sand & Indian Beach & Blue particles & $\begin{array}{l}\text { Clear with gray particles } \\
\text { salt and popper }\end{array}$ & $A B C$ \\
\hline Black coorso sand & Albine Engine & Large ble & $k$ particles in all throo & $A B C$ \\
\hline $\begin{array}{l}\text { White sandblasting } \\
\text { sand }\end{array}$ & Northwost Copper & Smooth white & Smooth white & $A B C$ \\
\hline Black sand & Gravol company & $\begin{array}{l}\text { Whito glaze, } \\
\text { black particles }\end{array}$ & Clear with large black particles & $A B C$ \\
\hline Bolge sand & Cape Lookout & $\begin{array}{l}\text { White with } \\
\text { blue particlos }\end{array}$ & Tan with brom particlos & $A B C$ \\
\hline
\end{tabular}

4 The lettors indicato tho basic glaze in which the additive is useablo. 
TABLE 2.--TEST RESULTS USING GRAVEL AND CRUSHED ROCKS

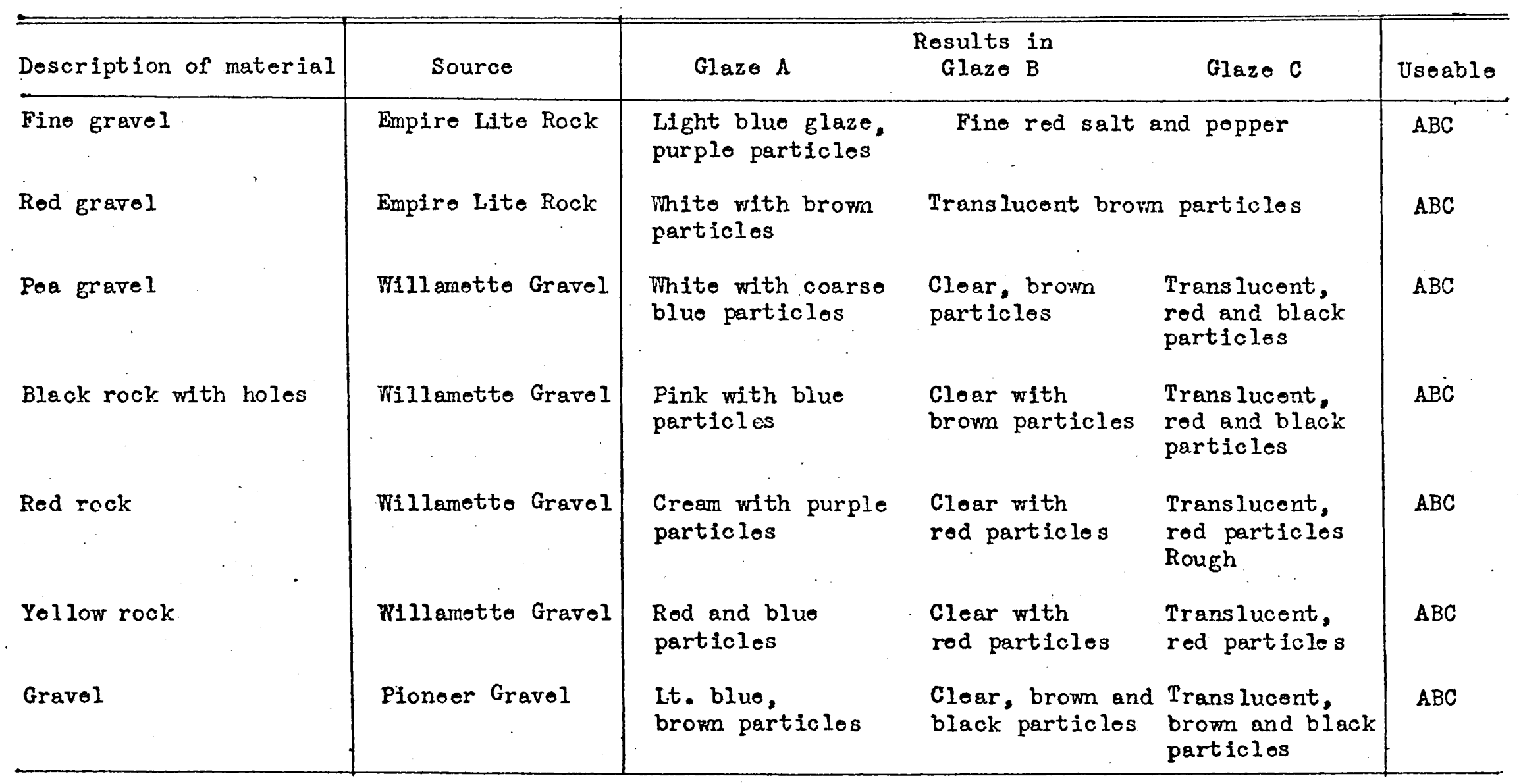


TABLE 3.--TEST RESULTS USING CLAYS AND SOILS

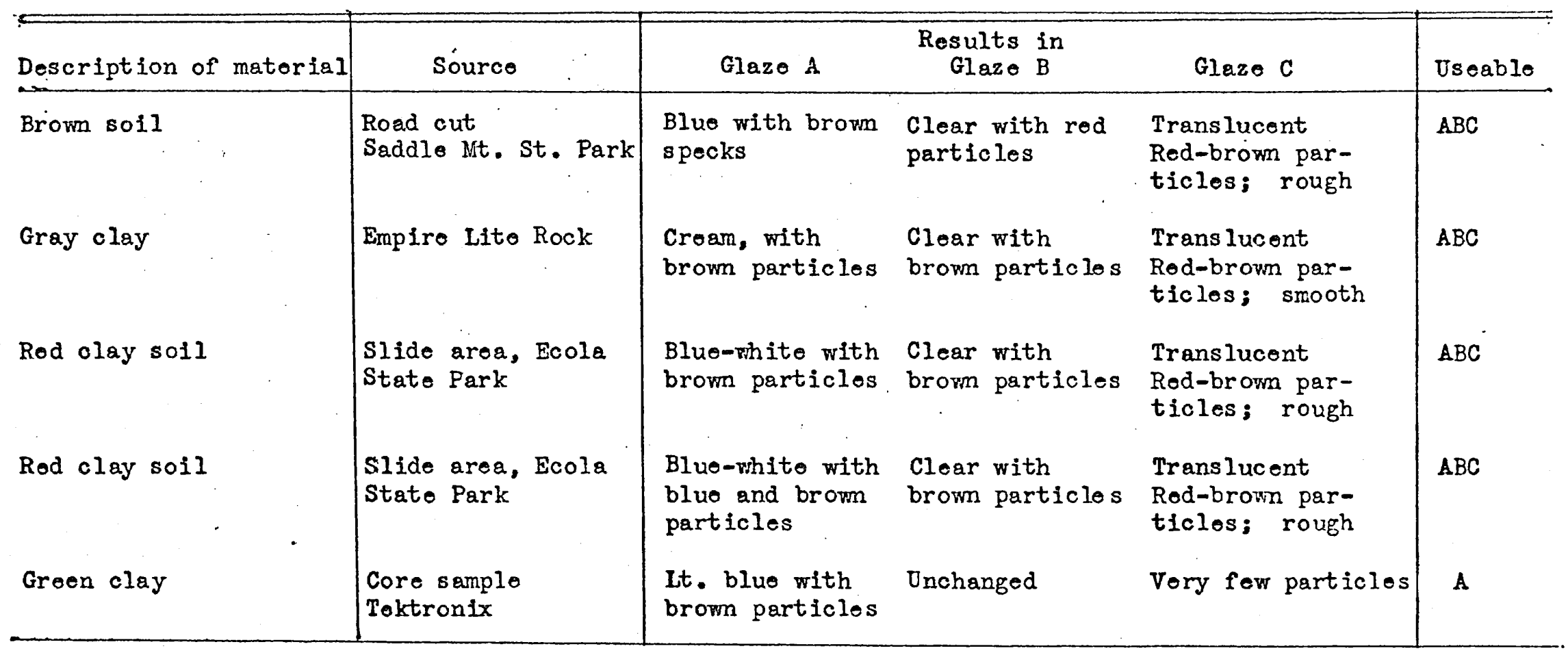


TABLE 4.-TEST RESULTS USING SLAG TAILTNGS

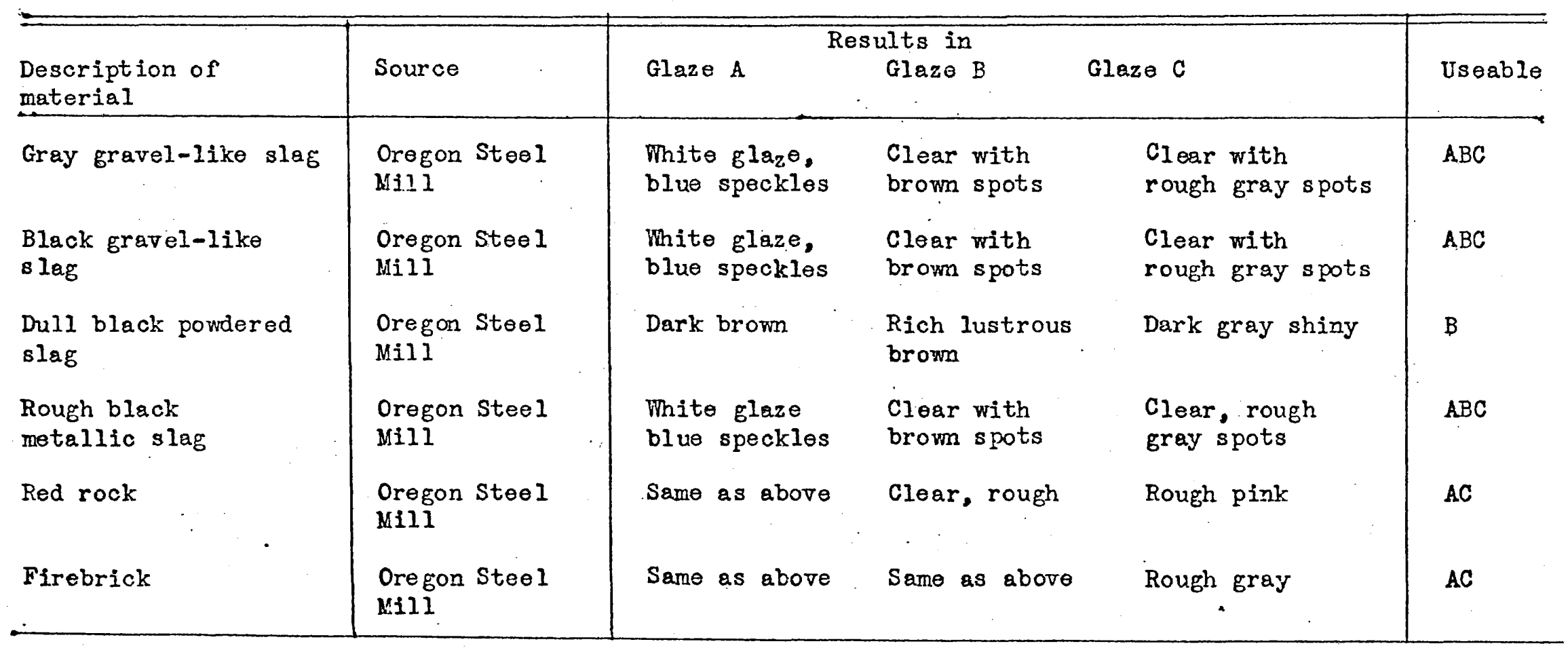


TABLE 5.--TEST RESULTS USING METAL FILINGS

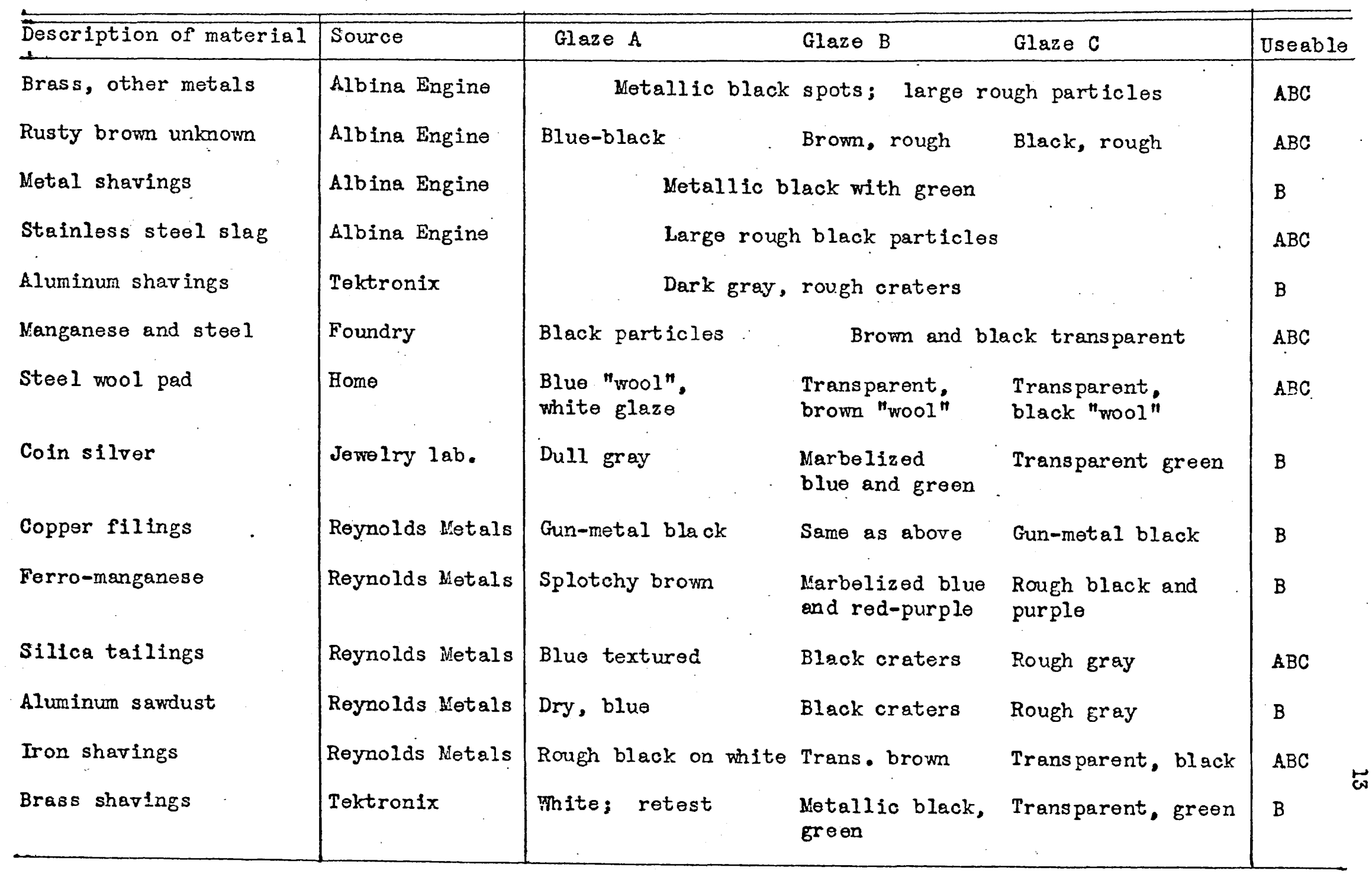


TABLE 6.-TEST PESULTS USING HISCELLANEOUS ITEUS

\begin{tabular}{|c|c|c|c|c|c|}
\hline Description of material & Source & Glaze A & $\begin{array}{l}\text { ults in } \\
\text { Glaze } B\end{array}$ & Glaze C & Useable \\
\hline Aspirin & Home & No change & any of the glazes & & None \\
\hline Bicarbonate of soda & Home & No change & any of the glazes & . & None \\
\hline Borateem & Home & No change & any of the glazes & & None \\
\hline Epsom salts & Home & No change & any of the glazes & & None \\
\hline Gypsum wallboard & Home & White iridescent & Translucent white & No change & $A B$ \\
\hline Sand dollars & Beach & Same as above & Same as above & Dry white spots & A \\
\hline Kitty litter & Neighbor & Rough $\tan$ & Rough white & $\begin{array}{l}\text { Rough pink and } \\
\text { white spots }\end{array}$ & $A B C$ \\
\hline Vermiculite & Cone boxes & $\begin{array}{l}\text { Tan and blue } \\
\text { fairly smooth, } \\
\text { bulky appearing }\end{array}$ & $\begin{array}{l}\text { Clear with } \\
\text { brown spots }\end{array}$ & $\begin{array}{l}\text { Clear with } \\
\text { brown spots }\end{array}$ & A \\
\hline
\end{tabular}


IV. ESTHETIC APPLICATION OF GLAZE TO CERAMIC POTS

In choosing a particular glaze for a particular pot, the foremost characteristics considered were the visual lightness or heaviness of the pot, and the fineness or coarseness of the texture of the glaze. Also considered was whether or not a piece of ware would contain food as some of the glazes would not be compatible with food.

All of the pottery shapes are simple and straightforward, and some are primitive in feeling. These pots were made to provide appropriate vehicles for glazes made from common raw materials. The bowl in Photograph No. 2 is strong in reeling, showing tho clay it came from and the fingermarks of the potter. Therefor $\theta$, it could be onhanced by a bright, colorful glaze. The glaze, made from copper filings, is a smooth, glossy blue-green, with metallic highlights in the center of the bowl caused by an oversupply of copper. The outside of the bowl, where the glaze was poured thinner, has a green salt-and-pepper offect.

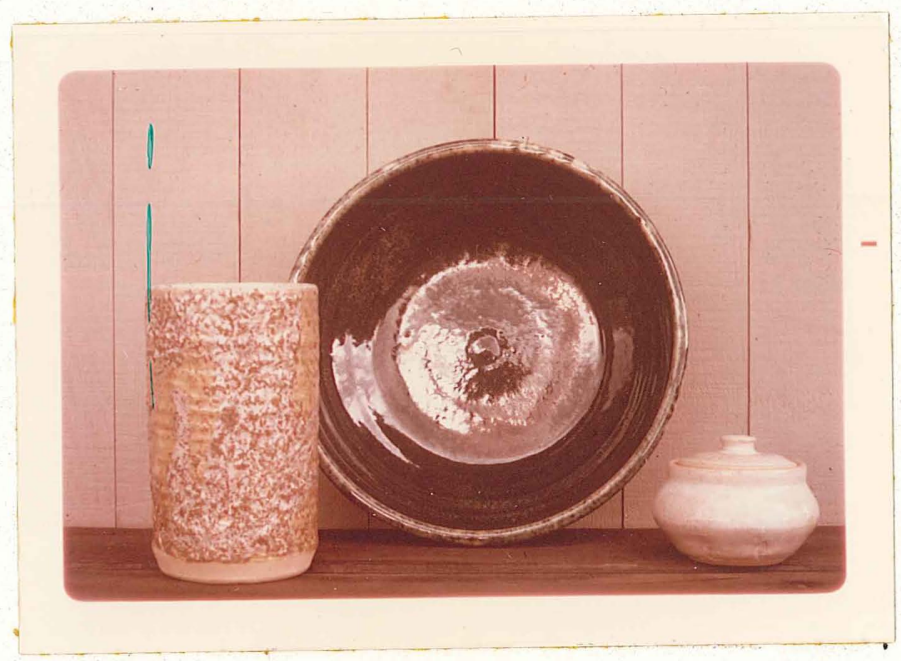

Photograph No. 2

Cylinder, bowl and covered jar. 
The cylinder, primitive in form, provides a compatible base for the bulky brown and blue-white textured glaze made from vermiculito. The small covered jar is more refined, making a harmonious combination with the iridescent elegance of the gypsum glaze.

Photograph No. 3 shows two entirely different results achieved by adding two different scrap metals to different batches of the samo basic glaze. The low bowl has a glossy, marbelized blue and redpurple glaze, highlighted with metallic black areas. This glaze is mado from a motal called ferro-manganese. In contrast, the small bott le has an extremely rough, sharpmedged texture, colorless except for the dark gray of the aluminum sawdust. This glaze may be suitable for large coramic sculptures which require a visual, rather than a tactile, texture.

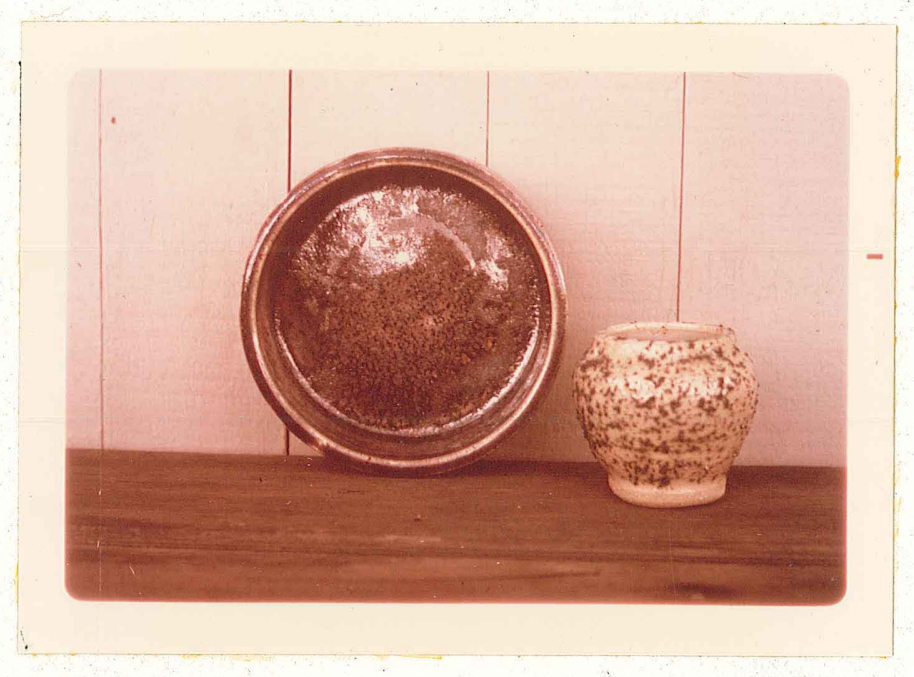

Photograph No. 3 Bowl and small bottle. 
In Fhotograph No. 4, there are neutral colors; the coverod jar shows a unity of the clay with the sand in the glaze, providing a subtle overall texture. The small bottle has a delicate texture throughout the glaze, produced by fine particlos of the sand. Coarser sand highlights the curved edges of the pioce.

The plate has some coarse particles, as well as green and motallic black docoration made by pieces of an unknown metal, possibly brass, found in the waste bins of a machine company. The black area was made by allowing a large concentration of the additives to remain on the plate during the glazing process to seo what effeot they would have on the flnishod glaze.

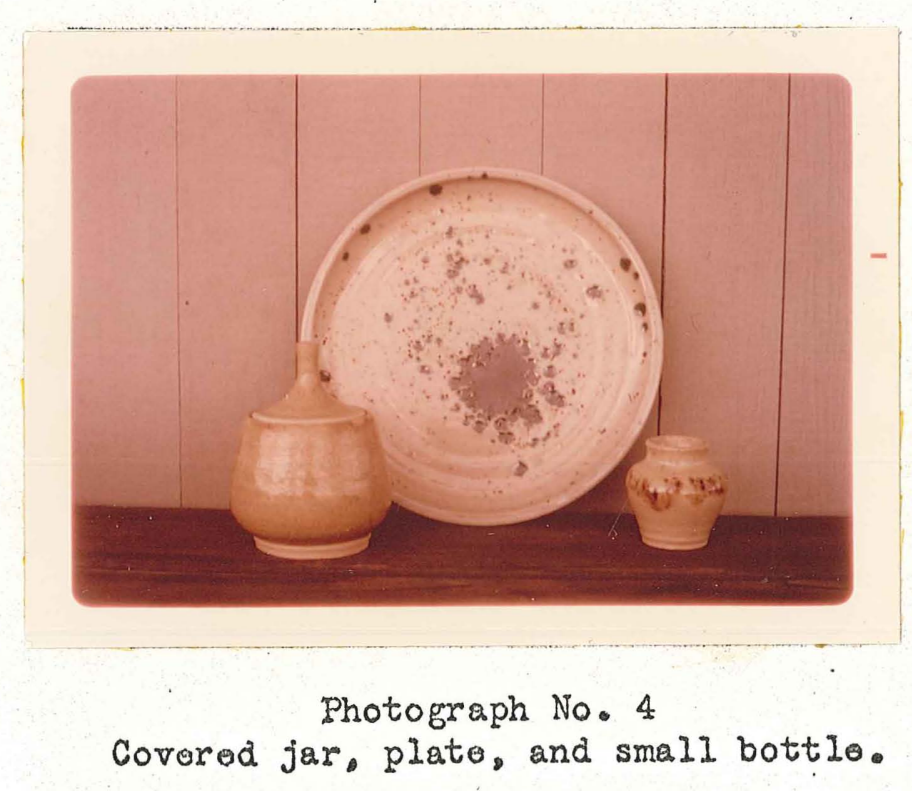


The bowl in Photograph No. 5 has baach sand in the glaze, which appears as blue particles, and gives tho glaze a toxture which foels. dry

The coverod jar has brass shavings in the glazo, which made the green and black markings where the brass melted and ran. These accen= tuate the curve of the jar. The vase has a rich brown glaze, resulting from the iron in the slag tailings from which it was mado. This Iustrous glaze enhances the curved shape, making a decorativo vaso.

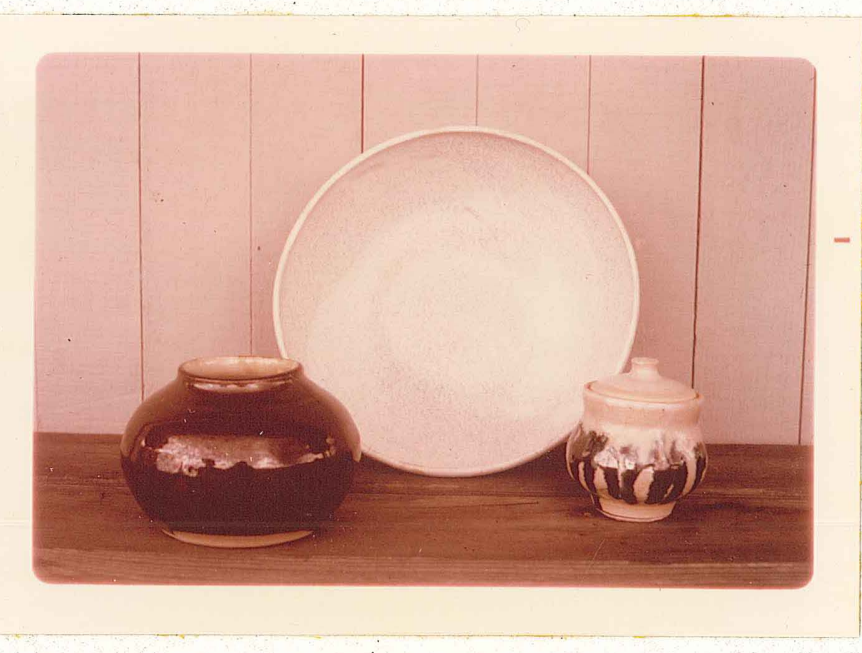

Photograph No. 5

Vase, bowl, and covered jar. 


\section{APPLICATION TO SECONDARY SCHOOL TEACHING}

This project can form the basis for a unit on glaze study for a secondary school classroom ceramics program. The unit can oxcite tho pupils to use their imagination and search the countryside for suitable materials to add to the glazes. The pupils would need to discuss the difference betwe on organic and inorganic matter and suggest sources of ingredients.

Although there are only throe basic glazes, the students would have a wide variation in them because of the great number of changes that additions can produco. The students would have tho opportunity to $\mathrm{mix}$ the basic glazes themselves, which would involve the careful weighing, straining, and mixing of the glaze ingredients. Then the students would add their found materials and test them in varying amounts. The pupil could experiment to determine how coarse or fine the materials neod to bo to give the results ho likos the best. Although the teacher would know in most cases what the approximate results of the additives will be, he would let the student discover them for himself. For those students who may wish to study glazes more fully, this experience could serve as an introduction.

The actual building and decorating of the ware could lead to discussions of design, proportion, and applied design. One student could pursue that aspect of ceramics wich most appealed to him, or a group might work on a common problem. Hopefully, the students would branch out into areas not covered here, depending upon their interests.

In a general art program, the student would be allowed and encour- 
agod to pursue tho medium in which he is most interested after an initial experience in various media. Some students may be involvod in a ceramics project at the same time that others may be painting, others building threo-dimensional structures, while others are doing research in the field of art history, and the like. Each student would be encouraged to make a study in depth in his area of interest, of which there may be several during the yoar. 
VI. SUMMARY AND CONCLUSIONS

This study has show that the color and texture of a good basic glazo can be changed by adding such items to it as vermiculite, copper filings, or crushed rocks. The basic glazes were colorless. Of fiftytwo ingredients tested, forty-six of these ingredients effected a change in the color or texture, or both, in at least.one of the threo basic glazes.

Several of the glaze mixtures show promise and could be tested and developed into good, useable, colorful glazes: specifically, the copper filings, the forro-manganese, and the slag tailings from the steel-mill. For textured glazes, additional studies could bo developed on several of the sands using lesser amounts and on the gravels using finer particles.

In a classroom without adequato ventilation, it would be unwise to fire in an electric kiln anything which is in any way questionable. Plastics should not be used because they create an obnoxious odor which is perhaps toxic. Salt (sodium chlorido) producos chlorino gas, which is poisonous. It also creates a salt-glazo on the inside of tho kiln, which would salt-glaze any subsequent firings. All organic materials would burn out during the firing.

This practical use of common ingredients provides many opportunities to interest secondary school students in the study of glezes. 


\section{BIBLIOGRAPHY}

1. Ball, F. Carlton. Cones 5 and 6 matt glazes. Ceramics Monthly, 8:35. May 1960 .

2. Glaze \#16 cone 3-6 transparent. Ceramics Monthly, 8:33. March 1960 .

3. Green, David. Understanding pottery glazes. London, Faber and Faber Limited, 1963. 128 p.

4. Leach, Bernard Howell. A potter's book. 6th ed. New York, Transatlantic Arts, 1953. 294 p.

5. Metals handbook. 1939 ed. Cleveland, American Society for Metals. $1803 \mathrm{p}$.

6. Nelson, Glenn C. Ceramics. Now York, Holt, Reinhart and Winston, 1960. 236 p.

7. Poor, Henry Varnum. A book of pottery. New Jersey, Prentice Hall, 1958. $192 \mathrm{p}$.

8. Rhodes, Daniel. Clay and glazes for the potter. Now York, Greenberg, 1957. $219 \mathrm{p}$. 
APPEND IX 
TABLE 1

METALIIC OXIDES USED TO PRODUCE COLORS IN GLAZES

Oxide

Porcent

Cobalt carbonate $\mathrm{CoCO}_{3} \ldots \ldots . . . . . . .1$

Copper carbonate $\mathrm{CuCO}_{3}$......... . . 6

Forric oxido (Red iron) $\mathrm{Fo}_{2} \mathrm{O}_{3}$..... 10

Manganose dioxido $\mathrm{MnO}_{2}$.......... 5

Tin oxido $\mathrm{SnO}_{2}$............. 7

Titanium dioxide (Rutile) $\mathrm{TiO}_{2}$..... 10

TABLE 2

MELTING POINTS OF SELECTED COMPOUNDS AND METALS

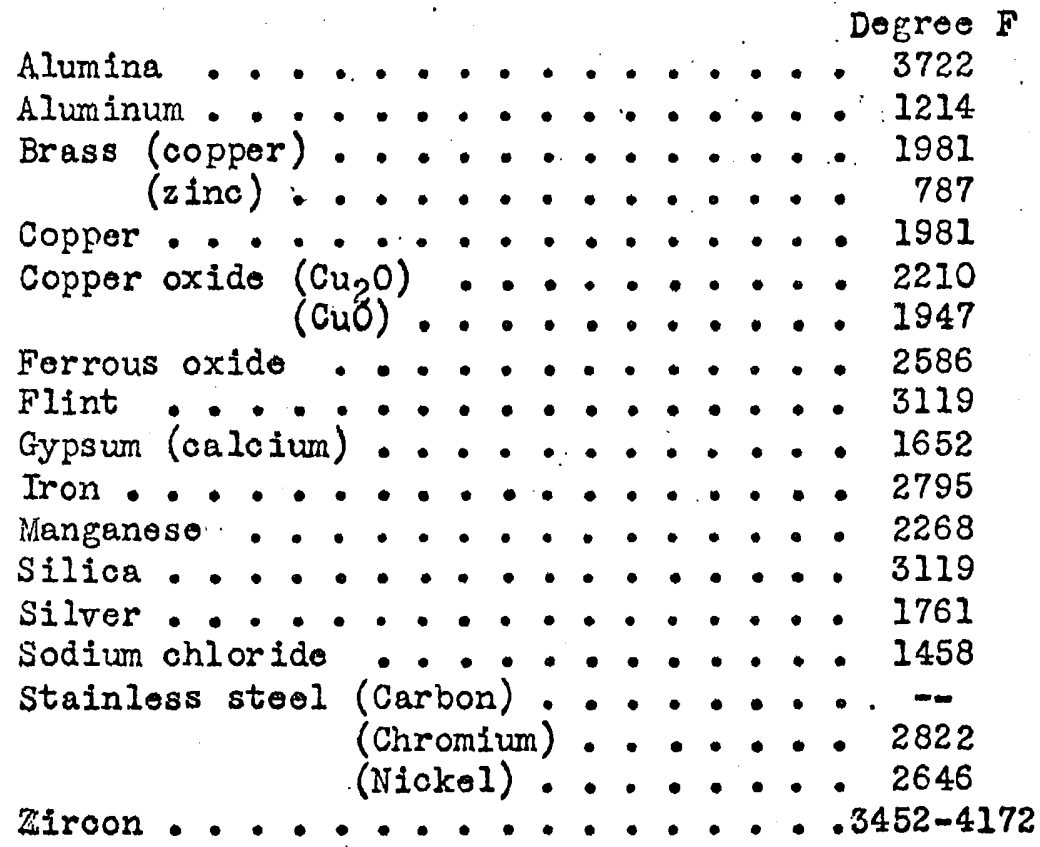

